\title{
REUSE OF DJENANE ABD-EL-TIF, AN EMBLEMATIC ISLAMIC GARDEN IN ALGIERS
}

Malika Hocine

Naima Chabbi-Chemrouk

\author{
Ecole Polytechnique d'Architecture et d'Urbanisme, \\ EPAU, Laboratoire Architecture et Environnement, LAE. \\ Algiers, Algeria \\ hocinemalika@gmail.com \\ Ecole Polytechnique d'Architecture et d'Urbanisme, \\ EPAU, Laboratoire Architecture et Environnement, LAE. \\ Algiers, Algeria \\ naima.chemrouk@gmail.com
}

Received: March $30^{\text {th }} 2015$; Accepted: May 25 $5^{\text {th }} 2015$; Available Online: June $15^{\text {th }} 2015$

\begin{abstract}
Djenane Abd-el-Tif is an example of an Algerian summer residence dating from the Ottoman era. This type of building is not very well-known and remains marginalized in research that is more interested in the townhouses of the medina of Algiers. Yet, the gardens, the ingenious irrigation systems, fountains, and other patterns of Islamic gardens make of these djenane a unique typology worth exploring and preserving. Indeed, Islamic garden design is an art in itself and any restoration or conservation work should preserve the authenticity of its characteristics. The djenane Abd-el-Tif was fully restored following the damage caused by the Boumerdès earthquake in 2003. This led to the discovery of various elements that are particularly informative about its architecture and composition. It also highlighted the existence of valuable Islamic garden patterns, together with the djenane's exceptional flora, which could provide added-value to the tourism potential of such residences. However, if restoration work has saved the djenane Abd-el-Tif, its garden with its Islamic design characteristics is not yet fully investigated nor listed as a cultural heritage. This article presents the djenane as a cultural heritage and argues that right restoration and reuse could contribute to enhancing knowledge about Islamic garden design in North Africa.
\end{abstract}

Keywords: Djenane; islamic garden; Medina of Algiers; reuse.

\section{Introduction}

Since Ottoman times [1][2] the medina of Algiers has seen significant architectural and urban development due principally to maritime activities [3]. The wealth created by these activities has not only been materialized in a multitude of buildings and landmarks (fondouks, houses, mosques, palaces, villas, etc.) in the medina, but also in the construction of graceful, large country homes known as djenane, located in the fohos on the outskirts of the medina. These extramural buildings provided a place for recreation, while their gardens were a source of produce [4].

Unfortunately, today, these djenane whose architecture, location and gardens constitute a rich patrimony have received very little attention, and therefore little is known about them. This research highlights their cultural heritage and their potential contribution to tourism.

\section{The Djenane, Location and Composition}

The djenane were located on the outskirts of the medina of Algiers, in the fohos. At other times they were also known as Diar el Fahs (Figure 1). They belonged to Turkish dignitaries, or the Moorish or Algerian bourgeois [5].

Their owners saw them as a place of refuge from the summer heat, and they were also known as summer residences [6]. Located far above sea level, the air was clean and healthy, and cooled by sea breezes from the beginning of the summer months.

Unlike the main townhouses, the gardens of the djenane included orchards and ornamental plants. Olive and palm trees mixed with exotic fragrances and the gardens provided both recreation and pleasure facilities as well as being a source of food [7]. Their broad green expanses were unfenced and simply delineated by hedges of myrtle, hawthorn, aloe and Barbary figs [8]. The gardens, vegetable plots, the abundant water and irrigation systems, fountains, and ornamental ponds clearly distinguished them from the townhouses of the medina. Cotereau [9] used a biological comparison, referring to a branched cell compared to the contracted cell that was the 
townhouse. The sprawling djenane with their extensive gardens were a demonstration of the prestige and wealth of their owners. Their importance was expressed through the area they covered, the footprint of buildings, their rich composition and sumptuous decoration [10].

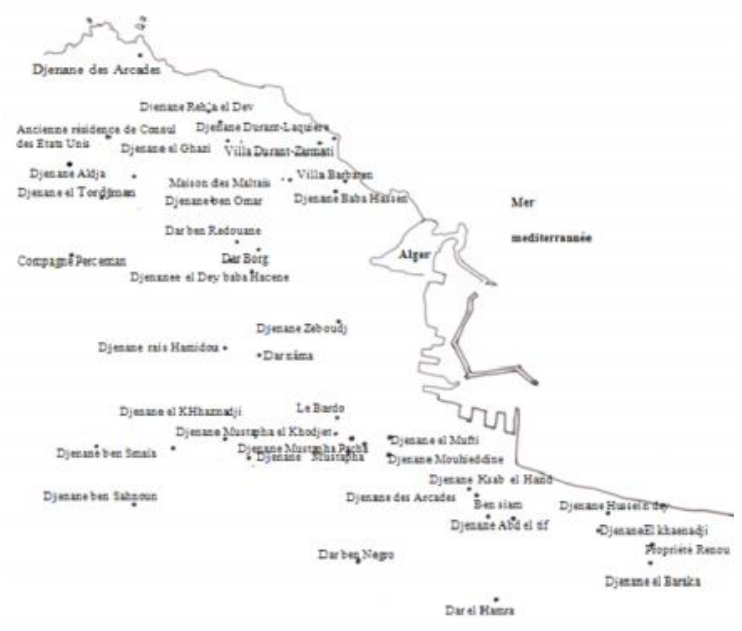

Figure 1: Location of djenane in the vast green fohos of the medina of Algier (sources: i) M. PHILIBERT, Le Fah'ç algérois d'antan, Ronéote, Alger, 1970, pp. 1520; and ii) SAIDOUNI N., La vie rurale dans l'Algérois de 1791 à 1830. Doctoral thesis, University of Provence, Aix, Marseille I. Faculty of Arts and Humanities. 1987/1988.)

\section{A Typology of Djenane}

Not all djenane are the same [11]. Two main typologies can be distinguished:

Official residences: Official residences were used by the Dey and his entourage as a place where he could live with his family during the hottest months of summer, while continuing to carry out official functions. These residences comprise a private area consisting of various courtyards with gardens, orchards, ornamental trees, flower beds, ponds, and pavilions. A second, official section consisted of a vast building with a large meeting room and reception areas, together with a guardhouse at the entrance to the gardens.

Private residences: Private residences belonged to rich merchants or wealthy privateers. These were generally smaller, nonetheless luxurious, buildings with tropical vegetation including olive and palm trees and more exotic species. They do not have a large meeting room, and often not even a sqifa (entrance hall) as guests were welcomed at the entrance to the gardens. This type djenane took two forms:

i. The first was the transposition of the townhouse to the countryside, with just a few detailed differences; larger windows opening to the outside, and the absence or reduction of the sqifa;

ii. The other consisted of various pavilions that were distributed around water features and fountains, which created units that were wellventilated by numerous windows. The single-storey decorated porticos of ancillary buildings had multiple openings onto the gardens, waterfalls and marble fountains.

\section{The Djenane Abd-el-Tif}

The djenane Abd-el-Tif falls into the second category of djenane. Located on the outskirts of the medina of Algiers, it is a representative example of the genre. It was classified as a national historical monument in 1922 and 1967 (Decree No. 67-281 of $20 / 12 / 1967$ ) both for its architectural interest [12] and its status as an example of the djenane of the Algiers fohos [13] . It should be noted, however, that the garden is not classified.

The djenane Abd-el-Tif is situated on one of the greenest sites of the southern massif of the medina of Algiers, namely the Fah of Bab Azzoun. Considered to be the better side, given its water sources and gentle topography, the massif is known as the 'green wing' of Algiers [14]. It enjoys the most beautiful, pleasant countryside and its picturesque houses all have a sea view.

The djenane Abd-el-Tif is considered to be one of the oldest djenane in Algiers, as the first document that mentions it dates from 1715 and it is believed to have belonged to Ali Agha. The last owner was Mahmoud Ben Abd-el-Tif, the bach kateb (chancellor) of the Deys, Mustapha Pasha and Hassen Pasha, who bought it in 1795.

At that time, the djenane Abd-el-Tif consisted of the main house, the douera (an ancillary building) the riad (a building with an interior courtyard) and the portico. Figure 2 shows that a much greater area was given to the garden, confirming the djenane's prestige and vast extent (Figure 2).

In practice, the Djenane Abd-el-Tif has the same composition as a townhouse in the medina but with differences in:

- Spatial organization: the douera is not integrated into the main house, but remains within the perimeter as both open onto the same interior courtyard.

- The presence of gardens, courtyards and vegetable gardens.

- The abundance of water: fountains, ornamental ponds and springs.

- Large spaces. 
- Large doors and windows that open onto the garden.

- The diversity of spaces: porticos and others.

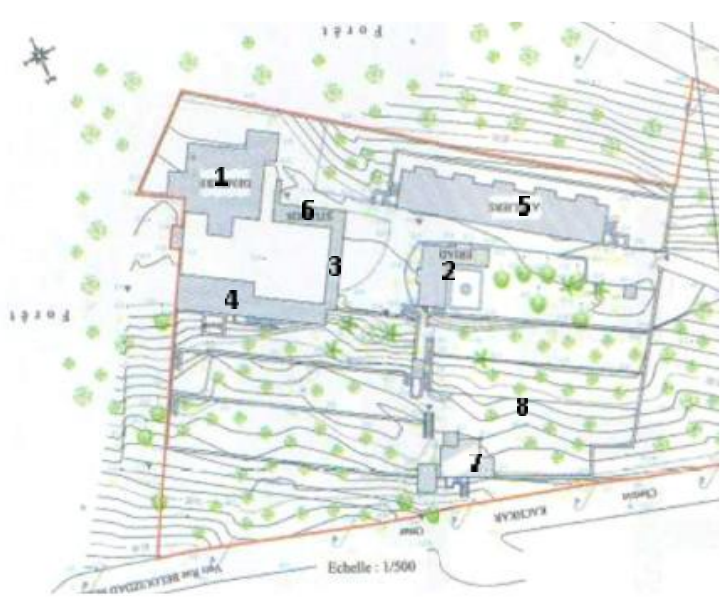

\begin{tabular}{|l|l|}
\hline $\mathbf{1}$ & La Demeure principale \\
\hline $\mathbf{2}$ & Le Riad \\
\hline $\mathbf{3}$ & La Douera \\
\hline $\mathbf{4}$ & Le Portique \\
\hline $\mathbf{5}$ & Les Ateliers \\
\hline $\mathbf{6}$ & Les Studios \\
\hline $\mathbf{7}$ & La Villa \\
\hline $\mathbf{8}$ & Les Jardins \\
\hline
\end{tabular}

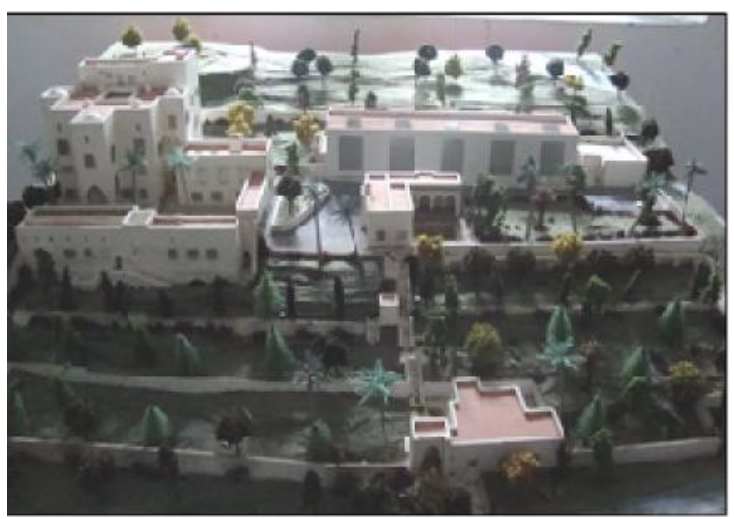

Figure 2. The architecture of the djenane Abd-el-Tif (Source: Cabinet d'architecture de design et des technologies de constructionPhoto: Personal collection (model of the djenane Abd-el-Tif), 2012)

Esquer [15] confirms that, like townhouses, the interior of these villas was decorated with tiles and carved woodwork. The latter had bigger rooms and courtyards, while the exterior of countryside villas was more welcoming. As country villas were isolated and without vis-à-vis, the windows offered a wide view over the garden, which became the principal element of their organization. The garden was the main feature of such houses: all spaces were organized around it and oriented towards it.

\section{The Articulation of Built/ Non-Built Space}

One of the original characteristics of the djenane is that they establish a balance between the mineral and vegetal. The mineral consists of the historic buildings, while the vegetal consists of the gardens that envelope them in greenery. In the words of Fromentin [16], these buildings, built in the middle of gardens, are one component of a verdant landscape. The djenane Abd-el-Tif is unusual because this balance has always been maintained, and the garden has survived despite the various transformations it has undergone since the French period.

The historic buildings and the garden are two elements of a composition designed to showcase their grandeur and beauty. Their staging creates a picturesque landscape, offering a wealth of hidden treasures and discoveries. It includes ornamental trees and water features, meandering watercourses around ornamental ponds, rich flower beds and precise alignments that ensure a balanced and harmonious composition.

\section{References to the Art of Islamic Gardens}

The inspiration of the Islamic garden comes from the Muslim vision of Paradise described by God in the Koran. The Janna (Paradise) article in the Encyclopaedia of Islam outlines some of the pleasures enumerated in the Koran [17], which describes the gardens as sublime. They are filled with bubbling fountains, suffused by an aroma of camphor and ginger, crossed by lively rivulets, and wide areas of shade are provided by magnificent, rare and mature trees. There is a profusion of fruits in every season and pavilions welcome the faithful. Beds of beautiful and precious plants are divided by freshwater channels. A tracery of paths provides a route through this perfect landscape. Each element of the garden represents a symbolic reference to Paradise as described in the Koran.

Based on this description, man tried to replicate the pleasures of paradise on earth by creating gardens. These Islamic gardens, inspired by Islamic religious philosophy are enriched by cultural and geographical knowledge acquired during the various Muslim conquests in Mesopotamia, Asia, North Africa, Andalusia, and take into account the demands of the terrain and arid climate of this part of the world. They are characterized by the aspects described in the following sections. 


\section{Organization}

According to the Koran, the faithful will be rewarded by the splendour and abundant beauty of Paradise, therefore the garden is in this image. It is organized in a way that corresponds to its use as a space for relaxation and family walks. For this reason, gardens were developed on the basis of a division into many, linked, small courtyards and pavilions that together would provide a diversity of distractions connected by paths and alleys.

The organization of the garden of the djenane Abd-el-Tif is based on that of Islamic gardens. It is linked to its function as a place of relaxation and family walks, and not as a place of political and official meetings. It is therefore arranged into many dynamic, small spaces. These small spaces consist of the riad where the ornamental pond opens onto a green space, the greenery in the internal courtyard, and the gardens that slope away from the main building (Figure 3).
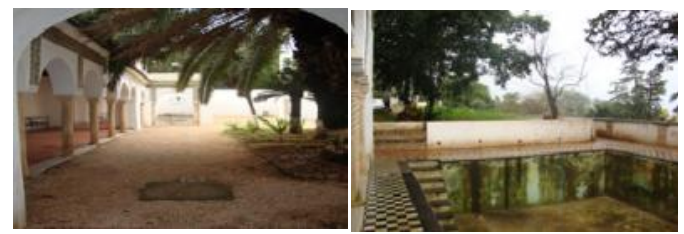

Figure 3. Small areas of the Djenane Abd-el-Tif used for relaxation and strolls (Source: Personal collection, 2012)

\section{Functions}

An important characteristic of Islamic gardens is that they cover a limited area and are surrounded by walls. The Koran describes the garden as an enclosed Paradise, where the righteous live in the greatest abundance as a reward to the faithful. Faithful Muslims are promised overflowing fountains, bubbling springs, fruit trees and squabs to rest upon under the shade of trees. This notion of an abundant, lush Paradise was important for the Muslim people who often found themselves short of water and faced with a difficult life in the desert. These lush gardens are not only a place of relaxation, pleasure and wellbeing; they are also places for contemplation and meditation on the power of God, eternity and the life cycle of the human being.

Like Islamic gardens, the djenane Abd-el-Tif is enclosed, which ensures a safe, protected space that constitutes a peaceful retreat from the intense heat of city life, daily tasks and the external world. It is therefore a place of relaxation, pleasure and well-being; a pleasant environment suited to family life.

\section{Planting}

The composition of Islamic gardens was characterized by rectilinear planting along alleys and in their sub-spaces. Certain trees were planted not only for the shade they provided (in a country known for its great heat), but also for their symbolic meanings. Evergreens (palm trees) represented the eternity of God, deciduous trees (such as the oak) represented the cycle of human existence (birth, life and death), while plants, like human beings, are born, live and return to the earth. The gardens of the djenane Abd-el-Tif follow these principles (Figure 5).

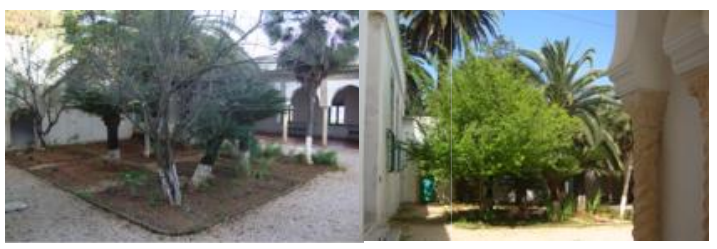

Figure 5. The symbolic meaning of planting at the Djenane Abd-el-Tif: Deciduous trees as symbols of the cycle of existence(Source: Personal collection, 2012)

This search for greenery and opportunities to admire it led to the architectural forms of the residence taking their inspiration from the plant forms in the garden. This provides continuity between the garden and the residence, which is seen, for example, in columns that resemble the trunks of trees, and plant or floral-decorated tiles that allude to the flowers and leaves found in the garden (Figure 6).

In a similar vein, all of the views from the main residence of the djenane directly overlook the various green areas surrounding the house (Figure 7).

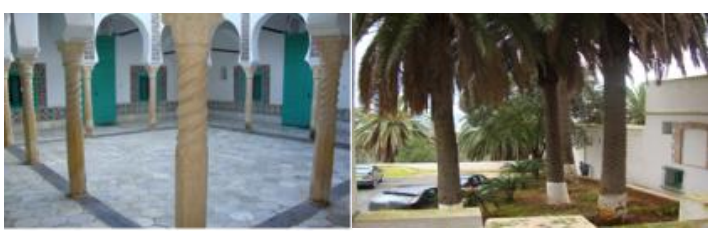

Figure 6. Continuity between the garden and the residence at the Djenane Abd-el-Tif: The allusion between the columns of the house and the trunks of trees found in the garden(Source: Personal collection)

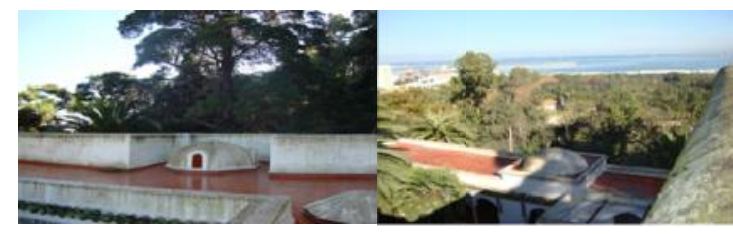

Figure 7: Views of the various green spaces from the main residence of the Djenane Abd-el-Tif(Source: Personal collection) 


\section{The Use of Water}

In the Koran, water is the source of life and purity. It is an important element for Muslim people living in harsh desert conditions, where water is a precious commodity, required for survival. The high demand for water, from both humans and gardens, requires careful management. Hence the judicious arrangement of pipes, ponds, fountains and reservoirs at the djenane. Its presence in the gardens represents the fertility, wealth and abundance promised to the faithful by God. It is therefore a symbol of reward, and demonstrates the munificence and goodness of God.

Islamic gardens are designed in the image of God's beauty and aim to maximize the pleasure of all the senses. They stimulate all of the senses and are therefore a model of a sensory and sensual approach, which takes the following forms:

- Vision: contrasting colours, the play of light and shade, reflections on water;

- Smell: the fragrance of plants and aromatic herbs;

- Hearing: the ubiquitous ripple of running water, the rustle of leaves and birdsong;

- Touch: the cool sea breeze and the variety of materials;

- Taste: delicious fruit trees.

The inspiration for the djenane, like that of Islamic gardens comes from the Muslim vision of Paradise and evokes beliefs related to the power and generosity of God and the Tree of Life [18]. They reflect the promises made by God to the faithful and in turn, express their will to honour and worship Him. The djenane Abd-el-Tif is therefore in the image of Islamic gardens both in terms of its organization and its functions.

Water is the soul of the djenane, and it is present in every part of the djenane Abd-el-Tif. It represents an element of continuity that links all its surfaces, but especially the garden. It finds its source in the well and the waterwheel, passing through the ornamental pond in the riad, and eventually reaching the fountain that is the focal point of the djenane, to ultimately arrive in the garden via irrigation canals (Figure 8). However, the presence of water must not only meet the demands of horticulture and irrigation, but also respond to aesthetic and acoustic needs.

This garden therefore provides everything that is needed for well-being. Not only do its shade, the fountain, and greenery offer an ideal space for leisure, rest and pleasure in the heat of summer, it is also a place for contemplation and meditation on the generosity and power of God, eternity, and the life cycle of the human being.

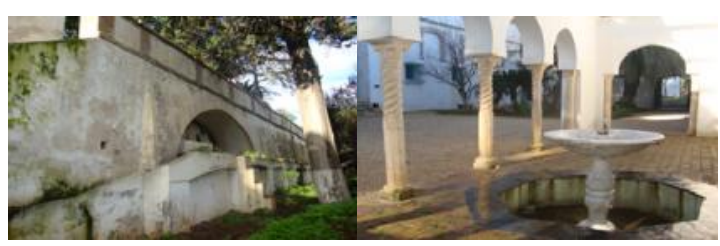

Figure 8. The use of water in the various spaces of the Djenane Abd-el-Tif(Source: Personal collection, 2012)

The composition, functions, choice of planting and use of water reflect the characteristics of Islamic gardens. In this sense, the garden has a dual value for visitors: it represents both the wealth and nobility of the Ottoman era, and showcases the botanic and ecological environment. From this perspective, it could be a driver for tourism and recreation, as it provides tourists with an insight into the culture and traditions of Algiers in the Ottoman period. Furthermore, it is an example of an Islamic garden, with an original, rich, complex and unique composition and could become a tourist destination in its own right. It could also be an addition to the development of tourism in the city of Algiers, through integration with existing attractions.

The djenane Abd-el-Tif already provides a place for relaxation. It could also fulfil both an educational and social function, and an environmental and ecological function. The djenane is a singular and original landmark, composed of historic buildings and its garden, and it can provide the public with a festive and enjoyable place to socialise. However, it is essential that if the djenane is to be developed for tourism, it must maintain its current configuration, and the balance between its constituent components (the garden and historic buildings) must be retained. To achieve this, it is first necessary to examine the transformations and various uses of the djenane Abd-el-Tif.

\section{Transformation and Uses of the Djenane Abd-el-Tif}

The first transformations of the djenane Abdel-Tif date from the French era, when it served as a hospital for soldiers of the Foreign Legion who needed a place to convalesce. It was particularly suited to this use due to its elevated, healthy situation, verdant greenery, the proximity of the sea and its location in the Bois des Arcades. This is probably also what saved it from the unfortunate 
fate of a great number of other djenane that were destroyed and ransacked at the time [19].

However, a report prepared in 1831 by the military stated that the djenane could only hold 150 beds. This number was considered insufficient, hence the decision to build a new building next to the main residence, in order to be able to accommodate a greater number of casualties [19]. Following the departure of the Foreign Legion to Spain, the djenane Abd-el-Tif was rented to the Compagnie fermière du Jardin d'Essai [Agriculture Testing Company], which occupied it until 1905 and used it for a permanent exhibition of agricultural and botanical products. It would eventually be transformed in 1907, into the Masion des artistes [Artist's Residence] until Algerian independence [20]. As such, it resembled the Villa Medici in Rome or the Casa de Velázquez in Madrid which is why the third French National Foundation named it the Villa Médicis algérienne.

The villa served as a home for artists from the metropolis who had won the Abd-el-Tif prize. It welcomed 89 residents who became known as the Abd-El-Tif. Between 1907 and 1961 they arrived at a rate of one to two per year, for a stay of one to two years [21]. The villa provided artists with a suitably inspiring and meditative atmosphere for their creative endeavours, which notably included representations of the various areas of the djenane. This new phenomenon helped to spread the word about the originality of the djenane's architecture, and it became much more widelyknown by the public (Figure 9). Furthermore, it encouraged visits by official delegations, who attended exhibitions of the work of the resident artists (such as in 1954 and 1959).

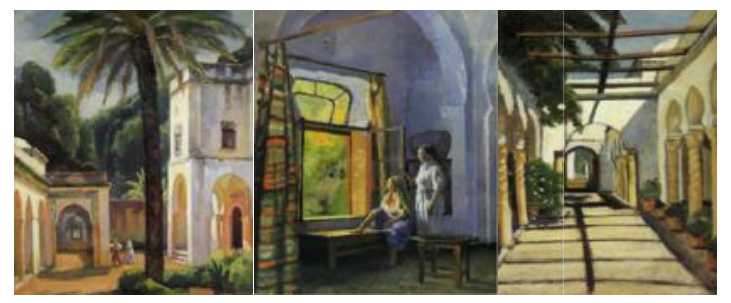

Figure 9: The role of art in the popularization of the Djenane Abd-el-Tif (Sources: E. Cazenave. La Villa Abdel-Tif : Un demi-siècle de vie artistique en Algérie

1907-1962, Association Abd-el-Tif, Paris, 2002, p. 335; M. Vidal-Bue, Alger et ses peintres (1830-1960), Edition Paris-Méditerranée, EDIF 2000, Paris-Alger, 2002, p. 47, pp. 207-209)

While this new use helped to promote the villa to tourists and contributed to its classification as a historical monument in 1922, the need to adapt to new requirements led to several transformations that changed the appearance of both its buildings and the garden. The most significant changes consisted in: the construction of a villa at the end of the gardens for the gardener and guardian in 1919; the transformation of the infirmary (dating back to the creation of the convalescent hospital in 1831) into a large hall for the exhibition of artist's work; the construction of five workshops reserved for working artists close the main entrance (beginning in 1929); the addition of a storey to the terrace of the main residence; and the backfilling of the ornamental pond in the riad with the addition of an ornamental bowl in the middle.

After independence, the djenane Abd-el-Tif was found in a state of abandon, which only became worse during the 1970s, when it was used to house a dozen families of Ministry of Information and Culture officials. The Ministry carried out several more transformations. Finally, the 2003 earthquake dealt the death blow to the djenane. Nevertheless, it was as a result of this disaster and the evacuation of the djenane's occupants that repairs were made and restoration work was undertaken.

\section{The Djenane Abd-el-Tif Post-Restoration}

Restoration work began in 2005. The aim was to restore the building to its pre-1830 appearance by recovering the structures and architecture that were closest to its initial state without completely ignoring or erasing the traces of other eras. This work also identified the original uses of its different spaces (such as the hamman that had been transformed into a bathroom). Furthermore, it led to the discovery of several elements that inform its architecture and composition such as:

- The backfilled ornamental pond in the interior courtyard and the buried fountain on the portico (Figure 12).

- The irrigation system that connects the riad's ornamental pond, the waterwheel and the garden (Figure 13).

The work took seven years to complete, and the djenane Abd-el-Tif has become the first example, since independence, of the restoration of one of the 120 djenane that still exist in Algiers.

Since 2008, the djenane has housed the Agence algérienne pour le rayonnement culturel [The Algerian Agency for Cultural Outreach] which is an agency under the Ministry of Culture. Their mission is to develop and organize Algerian cultural activities abroad and to contribute to the organization of foreign cultural events in Algeria. It also offers accommodation to working artists and welcomes the public, who are able to visit its different spaces and temporary exhibitions. 


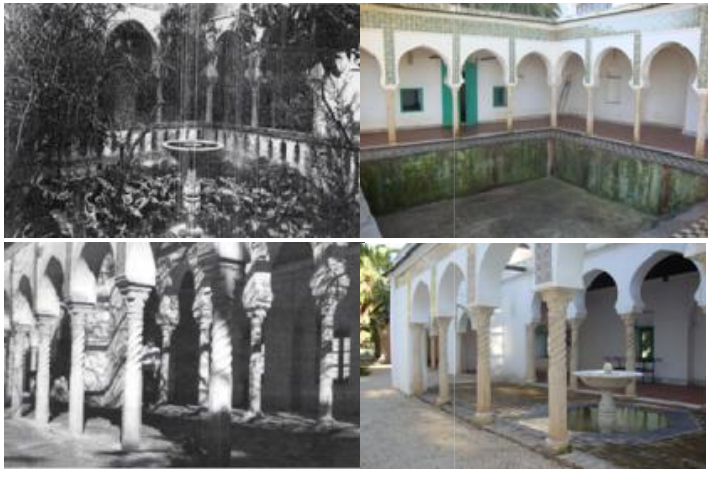

Figure 12. Architectural elements discovered during the restoration of the Djenane Abd-el-Tif (sources: IES archives of the Office National de Gestion et d'exploitation des Biens Culturels; Cazenave, E. La villa Abd-el-Tif : Un demi-siècle de vie artistique en Algérie 1907-1962, Association Abd-el-Tif, 2002, Paris, p. 26, 29; Photos: Personal collection, 2012)

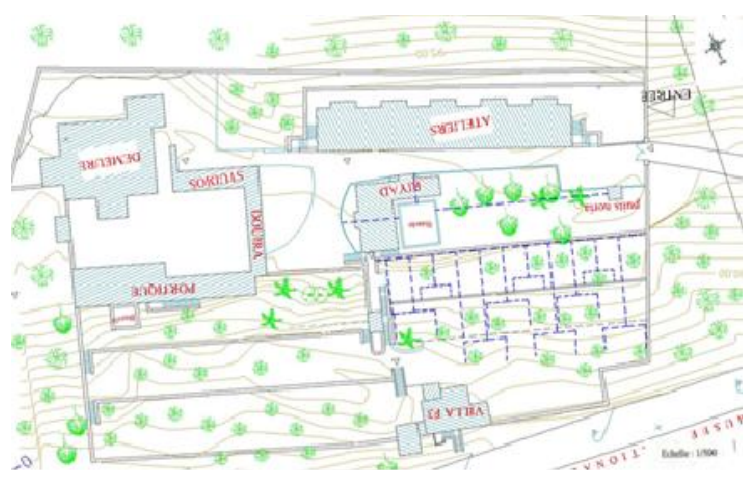

Figure 13: The irrigation system that linked the riad's ornamental pond, the waterwheel and the garden (Source: Cabinet architecture de design et des technologies de construction)

The work took seven years to complete, and the djenane Abd-el-Tif has become the first example, since independence, of the restoration of one of the 120 djenane that still exist in Algiers [25].

Since 2008, the djenane has housed the Agence algérienne pour le rayonnement culturel [The Algerian Agency for Cultural Outreach] which is an agency under the Ministry of Culture. Their mission is to develop and organize Algerian cultural activities abroad and to contribute to the organization of foreign cultural events in Algeria. It also offers accommodation to working artists and welcomes the public, who are able to visit its different spaces and temporary exhibitions.

We see that the djenane Abd-el-Tif, in addition to being open to the public, has resumed its former use as an artist's residence. Artists are able to use its workshops, the villa and a part of the main residence, where there is studio accommodation. However, their stays are restricted to a few months of the year and its more general use is as an administrative building. Consequently, its full potential is not exploited and there is a lack of visitors. The Islamic garden features and the originality of its buildings mean that the djenane Abd-el-Tif could become a principal tourist attraction.

\section{Conclusion}

The work undertaken in order to preserve the Djenane Abd-el-Tif led to the restoration of one of the most important djenane of the fohos of Algiers. It highlighted the harmony between vegetal and mineral functions and uncovered several elements specific to the djenane, which provide a benchmark for landscape design. These include the play of light and shade, the management of hydraulic, pumping and irrigation systems, and the multiplication of water channels. The gardens represent everything that can give pleasure to the five human senses: sight (colour, light and shade); smell (scented herbs and fragrant flowers); hearing (the murmur of water and noises created by the wind); touch (the textures of materials and plants); and taste (the flavour of fruits and herbs).

However, the current use of the landmark does not take these characteristics into account. Beyond the need for preservation, no attempt has been made to ensure the necessary integration of the monument into the cultural tourism market, both for the benefit of visitors and the landmark itself.

\section{Reference}

[1] F. CRESTI, Contribution à l'histoire d'Alger. Roma: Centro Analisi Sociale Progetti S.r.l, 1993, p. 96.

[2] M. Patel, Wind and Solar Power Systems. CRC Press, 2005.

[3] F. . . D. HAËDO, Topographie et histoire générale d'Alger. Paris, 1870, p. 90.

[4] L. De TASSY, Histoire du royaume d'Alger. Amsterdam: Henri du Sauzet, 1725, p. 20.

[5] P. Boyer, "L'évolution démographique des populations musulmanes du département d'Alger (1830/66-1948)," Rev. Africaine, vol. 98, p. 311, 1954.

[6] L. GOLVIN, Palais et demeures d'Alger à la période ottomane. Alger: INAS, 2003, p. 10.

[7] F. D. De HAËDO, Topographie et histoire générale d'Alger. Paris, 1870, p. 211.

[8] M. PERROT, Alger: Esquisse topographique et historique du royaume de la ville. Paris: Librairie Ladvocat, 1830, p. 37. 
[9] C. (M. J.), "La Maison Mauresque," Les chantiers nord-africains, Alger, p. 563, 1930.

[10] H. KLEIN, Feuillet d'El-Djezaïr. Visites et excursions des années 1910 et 1911. Alger: Imprimerie Orientale Fontana Frères, 1912, p. 59.

[11] L. GOLVIN, Palais et demeures d'Alger à la période ottomane. Alger: INAS, 2003, p. 127.

[12] E. CAZENAVE, La Villa Abd-el-Tif: Un demi-siècle de vie artistique en Algérie 1907-1962. Paris: Association Abd-el-Tif, 2002, p. 24.

[13] M. de la Culture, "La Villa Abdelatif." [Online]. Available: http://www.mculture.gov.dz/mc2/fr/gp_11.php

[Accessed: 30-Mar-2012].

[14] R. LESPES, Alger, étude de géographie de l'histoire urbaine. Paris: Alcan, 1930, p. 186.
[15] G. ESQUER, Alger et sa region. Paris: B. Arthaud, 1949, p. 106

[16] E. FROMENTIN, Sahara et sahel. Paris: E. PLON, NOURRIT and Cie, 1887, p. 198.

[17] G. H.A.R, J. R. Kramers, and E. L.Provencal, "L'encyclopédie de l'Islam," Leiden E-J-Brill. New Ed. G. $P$ Maisonneuve Larose S. A., vol. 2, pp. 1385-1388, 1991.

[18] I. M.-D. CORNY, Jardins du maroc. Paris: Le temps apprivoise, 1991, p. 170.

[19] H. Klein, Feuillet d'El-Djezaïr. Le Vieil Alger et l'occupation militaire Française. Alger: imprimerie orientale Fontana Frères et Cie, 1910, p. 10.

[20] L.-E. Angel, "Une maison algérienne des artistes," in LA VILLA ABD-EL-TIF, 1957, p. 2.

[21] E. Cazenave, La villa Abd-el-Tif: Un demisiècle de vie artistique en Algérie 19071962. Paris: Association Abd-el-Tif, 2002, p. 29. 